\title{
Explaining the Status of Feed in India; The Era of the Rule of Khodadadin Karnatic (1782-1799AD)
}

\author{
Khadija Alemi ${ }^{1}$ \\ ${ }^{1}$ Department of History, Faculty of Literature and Humanities, University of Tehran, Tehran, Iran \\ Correspondence: Khadija Alemi, Department of History, Faculty of Literature and Humanities, University of \\ Tehran, Tehran, Iran. E-mail: alemi1900@ut.ac.ir
}

Received: July 26, 2017

Accepted: July 31, 2017

Online Published: October 15, 2017

doi:10.5539/res.v9n4p34

URL: http://doi.org/10.5539/res.v9n4p34

\begin{abstract}
Food plays an important role in identifying the cultural manifestations of a community, and many factors influence the choice of food type. Different ethnic groups, based on their various requirements, customs, the type of culture and civilization, have developed various agricultural products as their food. The study of food, especially from a historical and cultural perspective, is a way of redefining the various forms of popular culture throughout history and its impact on the present culture. This article addresses the issue of how and during the reign of Khodadad, what has changed in the food of the people of the region of Deccan?

This claim has been studied in this research. Sultan Khodadad has issued a series of commemorations regarding the environmental, social, cultural and religious factors to bring about change and improve the situation in the Deccan population.
\end{abstract}

Keywords: feed, India, Carnatik, Khodadad

\section{Introduction}

The general sociologists and anthropologists agree on these concepts that folklore (including folklore) includes customs, myths, beliefs, religions, dialects as well as thousands of other social phenomena that are the true way of life, thoughts and feelings of the people. Public culture is important in maintaining the identity of the people. In other words, a community can be criticized through popular culture. Most folkloric or folk anthropologists believe that folklore is among all societies, and all people in towns and villages, and those who live in industrial cities and do not have much history, have popular culture. In spite of this, the domain of popular culture is wide.

Popular culture contains many of the measures that humans use to meet their basic needs, such as the provision of food, clothing, tools, and housing. Some people are proud of knowing their popular culture. Some people also pay attention to their place in society through the recognition of their culture. Registering and recording popular culture in order to familiarize young people with their past culture, identity to society, use of past heritage to solve today's problems, help deep understanding of official culture, especially literature and history, knowledge of society and people through popular culture and answering questions.

An example is the recognition of the popular culture of a community, their approach to the issue of food. In historical research, attention to the various aspects of human life is necessary. Historians in the past centuries have focused more on political events and on the description of wars, of the rise and collapse of governments, and less on linking history with other disciplines. In recent centuries, interdisciplinary studies have been instrumental in historical research. As the various aspects of human social life, the scholar of history has inevitably created a link between history and other sciences.

One way of achieving a clear picture of the social life of past peoples is to explore the culture of the public. Geographic and historical texts are important sources for the study of popular culture. The present research studies one of the aspects of folklore, namely, feed in these kinds of works. The research works on popular culture are abundant about various Islamic areas. So far hundreds of articles and a significant number of research papers on the anthropology of food have been written in the world, each of which has addressed a specific topic, but in Iran, it has not yet been substantially addressed.

Few books have been written about the cultural issues of feed, which are very few and unknown. There is also a small number of graduate and Ph.D. degrees. However, no research (In Iran, India and other countries) has ever 
done about the depiction of the popular culture of Deccan in the rule khodadad historical period. This article is based on geographic, historical, and documentary resources. The period under review in this article is the period of the rule of Sultan Khodadad in the Karnatak area of Deccan, which covers the years 1782-1799. Sultan Khodadad issued an order to improve the livelihood of the people and to create a change in the people's food. Therefore, the main emphasis in this research has been on Sultan Khodadad's commands. Hence, the orders of Sultan Khodadad, which are available in the State Archives of India as well as at the center of the Islamic Encyclopedia of Iran, are considered as the only important source in this field. However, there is no research in this area. Hence, addressing other issues, such as animal and beverage, requires independent research.

\section{Karnataka Geographic Location}

The Karnataka area is divided into two parts, coastal and non-coastal. The coastal area was divided into two parts of North Kanar and South Kanar, which started from the laborer in the south of Goa and extends to the Mangalore (Kabbur, 1984, pp. 25-51). Karnatak is part of the same area known as Moleibar, Moneibar and Malabar is considered one of the most important commercial centers in Deccan (Al-Ma'bari, 1987, p. 11).

The Deccan area is limited to the north by the cliffs of the Vindhya Mountains and the Narmada River, from the south to the highlands of the triangle known as the Kameron's nape, and from the west to the Ghats Western and from the east to the Eastern Ghats (Dordi Isfahani, No. 418, p. 2). This area includes the coastal areas and main plateau (Western Ghats or Sahyadri on the west coast, the northern plain of Deccan, the southern Deccan plateau, the Eastern Ghat on the east coast and the eastern plate of Deccan), which has five distinct geographic areas (Joshi, 1974, Vol. 1, p. 3).

Yazdani has divided Deccan into four main plateau areas, the Eastern and Western Gats, the West Coast and the East Ghat and the Gulf of Bengal (Yazdani, 1960, p. 5). Also, Maharashtra, Karnatic and Tilang are among the main areas of Deccan plateau (Joshi, 1974, Vol. 1, p. 4; Cunningham, 1871, p. 466). Maharashtra, Karnatic (now called Karnataka), and Andra Tilang (called Andra Pradesh) are now three separate states in southern India (Karami, 1373, p. 4). Ibn Battuta referred to sindabur as the first coastal city of the Moleibar region (Ibn Battuta, 1906, p. 557; Sharif Edrisi, 1989, 1/186) and writes:

"Sindabur consists of 63 villages. At the time of the tide, the waters of the island are sweet and tasty and in bitter and passionate fashion. There are two cities on the island, one old, one of the oldest buildings, and the new one built by Muslims" (Ibn Battuta, 1906, p. 553).

Ibn Battuta has not mentioned the name of two cities in sindabur, but it seems that the ancient city of the island is known as Goa and its new town called sindabur. Goa has also been featured in several maps on the island of Sindabur.

Quotation by Mahmoud Gavan shows that Goa Island is located exactly at Sindabur. He named the island, called Gowa, and introduced it to the famous Bayesian ports. He points out that from there he has gone to Bandar-e Hinur, while Ibn Majed and Ibn Battuta have also mentioned Hinur after Sindabur. Neemdehi is also writing: Gowa is located on the west coast (Bull, 1948, pp. 162-163; Ibn Majed, 1993, p. 393; Ibn Battuta, 1906, pp. 554-555; Neemdehi, Vol. 2, No. 271, p. 386A).

Alfonso Albuquerque writes in his memoir: Goa was surrounded by swamps and water on each side and it was difficult to get into it. The first people who settled in Goa were the Hindu tribes of Ticuarij. They built the ancient Goa and built towers in the castle to protect the island to prevent the arrival of Muslims. Then Dalboquerque writes: Goa was known as Ticuarij for the Hindus because of the Ticuarij tribal residence there (Dalboquerque, 1877, Vol. 2, p. 93).

After Sendabour, the coastal town of Hinur was located (Ibn Majed, 1993, p. 393). Abu al-Fida'a writes: "After Sindabur, go to the east and on the way to Belad Moleibar. There is a nice little area there, that has lots of bargains" (Abu al-Fida'a, 1840, p. 354). It was the place where large ships drove and were located half a mile from the sea, and during the rainy season, there was no possibility of traveling in the sea for four months (Ibn Battuta, 1906, pp. 554-555) was based on the Taghweem Al-Boldan after the small town of Hinur, Abi Sarur was located (Abu al-Fida'a, 1840, p. 354). This was a small urban area (Ibn Battuta, 1906, p. 559). After the Faknur, there was a town called Mangrur (Manjerur) (Al-Nadwi, 1979, p. 52; Neemdehi, Vol. 2, No. 271, p. 386A; Samarqhandi, 2004, p. 2/529). Ibn Battuta has traveled between Faknur and Mangror within three days. He describes it as a great city (Ibn Battuta, 1906, p. 560).

Abu al-Fida'a has also mentioned its geographic location in the east of Moleibar and its southern Aby Sarur (Basarur). He mentioned the distance between Mangrur and Hili in three days (Abu al-Fida'a, 1840, p. 354; 
Hamedani, 2005, pp. 38-39). Ibn Battuta introduced Hili as a great city that located next to the great harbor where large ships arrived (Ibn Battuta, 1906, p. 561).

Jarfatan was also a city of west coast cities (Sharif Edrisi, 1989, p. 1/186), from Hili to the Jarfatan. Three farsakh was the way, then there was Dahfatan. Dahfatan was the great city and was located next to harbor. It was also on the shores of Malibar. Ibn Battutah has visited this city and described it as a great city with a good port and fresh water (Ibn Battuta, 1906, p. 563). Then there was Findarina that was Abad (Sharif Edrisi, 1989, p. 1/186; Maghbul Ahmed, 1954, p. 65) and had gardens and beautiful markets (Ibn Battuta, 1906, pp. 563-564). Calicut can be mentioned from the most important cities of the Moleibar port. It was located next to Findrina, and was considered to be the center of the Moleibar (Al Nadwi, 1353, p. 51; Ibn Battutah, 1906, p. 564, p. 567; Neemdehi, Vol. 2, No. 271, p. 386A). Abdul Razzagh Samarqandi has introduced Calicut as a safe harbor (Samarqandi, 2004, p. 2/524; Ibn Battutah, 1906, p. 564). Chalyat was also a part of the Moleibar coastal cities (Abu al-Fida'a, 1840, p. 354). In this city scarlet fabrics were woven (Ibn Battuta, 1906, p. 572; Alemi, 2014, pp. 11-41).

\section{Khodadad in Power in Karnataka}

Shiite government of Mysore was formed when a large section of India involved in colonial. Government of Great Britain was achieved successes in the Indian; in central and northern India, independent states had been created that many rulers of them followed the rules and policies of Great Britain and from a hand they were in conflict with their neighbors and certainly in this divisions and interstate wars, what was damaged and destructed was India's Muslims force who were once homogeneous and united. At that time with the policy that Great Britain had, there wasn't unified India anymore and the Indian subcontinent was mired in lethargy (Abbas Zadeh, 2002, p. 77).

Local governments were not independent and followed Britain. But with all these dependencies all of them finally was destroyed and among them only Hyder Ali ruled that was independent remained. Hyder Ali was Shia and he was one of the main enemies of Great Britain. Mysore that was one of important states and it was in sensitive and a strategic region regarding the geographical location was in his territory. He fought not only with Britain but also with their neighbors that he suspected they wish presence of an alien (Abbas Zadeh, 2002, p. 81).

When Tipu in military school was passing high school, India was in chaos (Abbas Zadeh, 2002, pp. 72-73). For the first time in $1608 \mathrm{AD}$ it was contacted between the Gurkani government of India and Great Britain with the presence of Captain Hawkins in the court of Jahangir and after that, British government in 1615 AD sent Thomas Rone as ambassador to the Indian subcontinent and Britain activities began as the business from this date (Unknown, 1993, p. 110).

During the reign of Aurangzeb, the Europeans could not obtain the rights and privileges in the Indian subcontinent. Aurangzeb died in Deccan in $1707 \mathrm{AD}$ and after him, his son Shah Alam then his other son Bahadur Shah I ruled (Abbas Zadeh, 2002, p. 73). The two kings were involved in internal uprisings and widespread differences between religious and ethnic minorities (Jalali, 1996, p. 58). Tipu Sultan during the reign of his father was his minister and army obeyed him. After the death of Hyder Ali he followed in his father's anti-colonial politics. Hyder Ali and his son Tipu Sultan had sworn on the Quran to hate British forever and destroy them (Bungardelvin, 1982, p. 38).

British knew Tipu Sultan well and they were aware of anti-British goals and spirit of him. Hyder Ali and Tipu Sultan were difficult opponents that entered the hard failures to British and even it was close to destroy the British East India Company, but their scope was limited to the south and they did not have effect on the fate of the whole of India (Nehru, 1982, p. 1/455). Also the conditions had changed and Tipu Sultan was alone after death of his father. In the neighborhood of Mysore, people who hated Hyder Ali from old were not less and certainly these conditions made the influence of Britain more serious through neighbors (Abbas Zadeh, 2002, p. 87; Alemi \& Mousavi Salem, 2017, Vol. 9, No. 1, pp. 226-233). Under these circumstances, Typosslatan was concerned with the economic situation of Karnatk, especially agricultural issues. Hence, orders were issued to raise agricultural products and revenues from it, which was considered in this study.

\section{Bean and Grains}

\subsection{Rice, Pea, Beans, Wheat and Barley}

One of the food stuff that were used by people in Deccan were cereals and grains. The increase in the production of this product has always been in the hands of the Sultans, as Sultan Khodadad encouraged the cultivation of this product, and applied to reduce the farmers' tax on the product (Tipu sultan, 1873, p. 4), including products that were considered in this field were rice, peas, beans, wheat and barley (Tipu sultan, 1873, p. 4, p. 11, p. 12). 
Therefore, it has always been ruled out that the crops will not be reduced. The importance of the corn in Deccan was such that Sultan Khodadad ordered the perpetrators and commanders who receive the parcels of villages, forages, and so on. In his words, he banned the work and ordered only government officials to go to the villages to do this, and also urged the defendants to deny others other than government officials; if they did, they would be taken back by government agents (Tipu sultan, 1873, p. 11, pp. 37-38).

Cultivation of cereals, which was considered to be the main food of people in the Deccan region, was more than the other products of the sultans. As they ordered the people to give people who have agricultural land to cultivate this product and not leave the land without cropping; otherwise, the crop will be taken from the farmers (Tipu sultan, 1873, pp. 17-18). This is a formidable order that has also been punished.

The importance of rice production was such that the Portuguese had already built a castle to monitor rice exports. They banned trade of rice from the ports of Hennur, Baselur and Mangalore to Goa and the Arabian lands. Ibn Battuta, when he speaks of Dhafar, Qalhat and other ports of the south of the Arabian Peninsula, mentions that rice was brought there from the land of India (Ibn Battuta, 1968, pp. 251-262; Al-Ma'bari, 1987, p. 111).

\section{Trees and Fruits}

\subsection{Coconut}

One of the fruits that were used in carnatic is coconut. The coconut is the same as the Indian nutmeg (Ibn Battuta, 1968, pp. 255-562; al-Ma'bari, 1987, p. 73). The Sultans paid attention to the cultivation of this crop and provided that if the landlords started their garden initially with coconut, they would be exempted from tax for four years and in the fifth year, the tax is halved and taken from the sixth year as usual (Tipu sultan, 1873, p. 7).

To encourage coconut farmers, it was stipulated in these gardens to plant vegetables, etc., to give it to themselves and not to receive anything as a tax (Tipu sultan, 1873, p. 7). It was based on the Taghweem Al-Boldan Abisarur is located after the small town of Hinur (Abu al-Fida'a, 1840, p. 354). It was a small urban area with many coconut trees (Ibn Battuta, 1906, p. 559). Dahfatan was located next to Harbor and had many gardens, including coconut trees (Ibn Battuta, 1968, p. 563).

Sultan Khodadad also took care to seize it if the gardens of the supari and the coconut, which did not inherit, were seized or captured by anyone and did not give the land or produce to the government officials. Order public servants to cultivate the land effectively and increase the trees and vegetables and write their descriptions and record their products at the Sarkar Office. This includes all Muslims and non-Muslims, as some Hindus did not pay taxes, while the gardens were seized, their land was also seized (Tipu sultan, 1873, p. 5).

Al-Ma'bari writes: Barhamni was the most ambitious group of people who were divided into several groups. The group, which was ranked lower than the companions of the Khoyut, was known to be among the militarized armies and also the highest in number and number, divided into several categories, and the group was ranked lower and the others ranked above and a group was among the two. The lower group of Nayyar was Fazaniyan who used to grow from coconut trees (ibn Battuta, 1968, pp. 255-562; Al-Ma'bari, 1987, p. 73), to pour their seeds on the ground, and water it to create Khamer or Cooking and making sugar.

When the Arabs were convinced by the opposition of most Muslims and Sameri, they were fully prepared to go out from cochi and on Saturday morning, on the third day of Jommadi, the same year, they went to Fannan and burned most homes, shops and some mosques, and more the coconut trees were cut off on the banks of its rivers, and many Muslims were martyred. During the Portuguese presence in Deccan, the coconut trade was at the disposal of Muslims (Ibn Battuta, 1968, p. 670).

The coconut tree was used in the construction of ships. The harbor of the Portuguese ships is called the Mesmariyat (Al-Ma'bari, 1987, p. 77). Mesmariyat means the crew used to make the nail. But the Marakeb (known as the Javanese) used in the Indian Ocean and the Red Sea was made with coconut fibers without the use of nails and was less durable regarding building and was unsuitable for transportation of balls (Ibn Jobeir, 1967, p. 41; Ibn Battutah, 1968, p. 255; Al-Ma'bari, 1987, p. 77; Hourani, 1963, pp. 91-97; Correia, 1981, p. 165).

\subsection{Mango and Other Fruits}

Also, Soltan Khodadad ordered to plant in the best lands, in every position, two hundred mango trees and other fruits, to report on it and report on the quality of it to the ruler (Tipu sultan, 1873, p. 5). This command appears to be an example of a pattern of cultivation. On the other hand, the amount of land, the weather, the type of soil and the number of seedlings planted were considered by Sultan Khodadad. Other fruit trees such as Siddhis and Plain Cucumber were also planted and ordered by the government to harvest such products from the fields of land and send them to the government (Tipu sultan, 1873, p. 6). All land was considered by the government and 
it was attempted to even plant cucumber products in the fields around the tower and the barrow and castle, and planted the fields, Beha trees and monjinar trees (Tipu sultan, 1873, p. 16).

\section{Berries and Spices}

\subsection{Pepper and Ginger}

Part of the Moleibar shores, which was part of the Karnatic land, enjoyed favorable weather conditions for the cultivation of spices and vegetables. In the early days of their trade, the Portuguese took pepper and ginger merchandise from the Muslims, and then they traded cinnamon, carnation, buckwheat (Ibn Battuta, 1968, p. 612), and other good products.

Business trips to the Arabian land, Malacca and Ashi (Al-Ma'bari, 1987, p. 110) and Dnaasri (ibn Sa'id, pp. 107-108; Tibbetts, 1981, p. 490; Al-Ma'bari, 1987, p. 110) and so on were only unique to the Portuguese. Hence, only the trade of betel, coconut, clothing, and the like, as well as the trip to the islands, konkan and Shulmandel (around the Qaeil) were monopolized by the Muslims (Ibn Battuta, 1968, p. 670; Gibb, 1929, p. 273; Al-Ma'bari, 1987, p. 111). Calikuti says in his Book:

The business of pepper and ginger is dedicated to itself and coconut to others (Calicuti, p. 22; Al-Ma'bari, 1987, p. 111). Ibn Battuta says: Most of the trees in Sumatra are coconut, betel and cloves. Gibb has translated the Betel into areca (Ibn Battuta, 1968, p. 670; Gibb, 1929, p. 273; Al-Ma'bari, 1987, p. 111).

\subsection{Sugarcane}

Sugarcane was one of the products that were carefully planted. The largest sugarcane product in the Karnatic area was a city called Faknur. The Factor was a great city, and sugarcane was one of the most sought after products in the city. Sugarcane was cultivated in this area and was unique (Neemdehi, Vol. 2, No. 271, p. 386A; Samarqandi, 2004, p. 2/556). Government orders have not been affected by the abundance of sugar cane. As Sultan Khodadad ordered, sugar cane should be abundantly cultivated, especially in areas suitable for cultivation and sugarcane cultivation. Otherwise, if someone fails to do so, they must pay for it and take twice as much sugar as they can be grown elsewhere (Tipu sultan, 1873, p. 2).

The great city of Dahfatan was located next to Harbor and had plenty of gardens. Coconut, pepper, betel, Tuna leaf (Tanboul), Ghaghas and bananas were products of this city and Budfatan is located On the coast of the Moleibar. Ibn Battuta has visited this city and described it as a great city with a good port and fresh water and described the betel from the products of this city (Ibn Battuta, 1906, p. 563), then Findarina was located (Sharif Idrissi, 1989, p. 65, p. 186), with beautiful gardens and markets (Ibn Battuta, 1906, pp. 563-564) and peppers of the most important of these products The city was considered (Maghboul Ahmad, 1954, p. 53).

\subsection{Tuna Leaf (Tanboul)}

The Tuna (Tanboul) tree is a tree planted in the grape tree round and does not have any fruit, and the purpose of the tabernacle is its leaf, and its leaves are arranged every day (Ibn Battuta, 1968, p. 254; Al-Ma'bari, 1987, p. 70). One of the first decrees of the Sultan of Khodadad is the importance of the Tuna leaf (Tanboul). He ordered: first, the public officials, the residents and the inhabitants of the ghasbah and the villages to gather and to disappoint them and give them Tuna leaf (Tanboul) (Tipu sultan, 1873, p. 1).

Farmers that first cultivate their gardens with Tuna leaf (Tanboul) are halved for three years, and from the fourth year of tax are customary (Tipu sultan, 1873, p. 6). Indian people value a lot for Tuna leaf (Tanboul); if a person goes to his home and gives him five branches of Tuna leaf (Tanboul), as if he had given him the whole world (Ibn Battuta, 1968, p. 254; Al-Ma'bari, 1987, p. 70).

Some Hindu tribes who lose one of their relatives, for one full year, prevent intercourse with women, eating meat and Tuna leaf (Tanboul), and shortening their hair and nails, and with this The habit never disagrees, but they do these things to be close to the atrocities (Al-Ma'bari, 1987, p. 70).

Dahfatan was one of the coastal towns of Karnatic, with many gardens. Tuna tree (Tanboul) was one of the products of this city and was found abundantly. Budfatan also was on the shores of Malibar. Ibn Battuta has visited this city and described it as a great city with a good port and fresh water and described the betel from the products of this city (Ibn Battuta, 1960, p. 563).

Two tourists named Nikitin and Barbosa have provided useful information on the economic conditions of the various cities of the city, especially its ports. Goods such as horses, slave, porcelain, glassware, carpets and fabrics from parts of China, Aleppo and Iran were issued to the west coast of the city of Deccan. Tuna leaf (Tanboul), was among the Deccan exports (Barbosa, 1989, pp. 158-181). 
The significance of the Tuna leaf (Tanboul) was such that there was a position with the name of the bastard in the subcontinent of India, and the Muslim sultans were also diligent in keeping this official (Fereshte, 1301, pp. 299-300; Khafi Khan, 1925, p. 3/39; Jakjiyon Dos).

\subsection{Salt}

Salt was one of the food items during the reign of Goddad. This commodity was scarce and expensive. As goddad paid more attention to his trade and deal, he issued orders about it. He ordered the following: Before that, the biopariants of the co-workers went to chanapatan, and bought salt and other goods. Now it is forbidden to travel to this place, and it is emphasized that the salt and other goods from each area that is close to the people to go and buy from there; such as Hinur, Marjan, Ankole, and Codyal, etc. If someone secretly goes to Chenapatan to buy salt and so on, he will work on salt and cattle and his life in the closet, and will be fine for him.

If the bioparticles of the Chenaptene Province come to the property of khodadad for Salt deal, take the cow and their property and salt, and put them in the bowl; and they are required to comply with the judgment to be guided and act by the law (Tipu sultan, 1873, pp. 27-28).

\section{Result}

The present study, which seeks to find the quality and quantity of feed in the sub-continent of India, by examining the reports in the historical and geographical texts, concluded that the feed elements in the Karnatak region affected by seasonal products and specific weather conditions in each region have been. But on the other hand, reports from historians and tourists show that the food of the people of this region has changed the impact of their jobs, agriculture.

The Karnataka area is one of the Indictlands in Deccan, which is very suitable for research on kharkak. Due to the abundant rainfall, this area has a varied spring with a varied vegetation. The mountainous region has made it possible for car plants and forests to be built around the villages of this region. The varietal variety of Carnatec has created the fasts appropriate to this nature.

Lifestyle, livelihood, religious and religious practices have caused the region's food to have special features. Therefore, Khodadad Soltan, with due regard to environmental, social, cultural and religious factors, issued orders to make changes and improvements in the situation of the people of Dehkan, as the significance of the tabernacle in the customs of the Indian subcontinent he cultivated those orders.

\section{Acknowledgements}

Anthropology is, in fact, an analysis of food within the framework of culture. Although the main purpose of nutrition is feed, it also has cultural dimensions, and in this context, it is a culture that people decide on what foods they consume or what to eat. This choice is not only due to the taste of the food, or the nutritional value of the food, but it is shaped by the environmental factors, the social, cultural, and religious base of the people. Food and nutrition have been of great importance to human beings.

Different species of beings, from the time of their emergence, require a military system to feed and provide a source of life and survival. Human beings were no exception. But what makes this topic more relevant to humans is the implication of the human nutrition system in the culture of human societies, which has led to its diversification and richness in the reach of cultures and societies. Apart from the impact of food on the macro, economic, political, social and cultural life of humans at a more limited level, this phenomenon is also of particular importance. In fact, food is heavily clustered with diverse cultural, social, and economic meanings and attributes that can be traced back to more and deeper insights from individuals and societies.

In fact, food is the point of intersection and the link between material and tangible culture and our immaterial intangible culture. Food, tools and supplies for food, table layout, apparent features of food, material dimensions and knowledge about the knowledge and use of these materials along with the cultural implications of food have the intangible dimensions of culture.

\section{References}

Abbas, Z. S. (2002). Tipu Sultan ambassador to freedom. Qom, Nurossajad.

Abolfeda, Emadeddin Ismail ibn Muhammad ibn omar. (1840). Taghwemol Boldan. Correcting Al-Baron Mack Kokin Disselan, Al-Tabaa al-Soltanieh, Paris.

Alemi, K. (2014). Moluk Bahmani the first independent Muslim rulers in Deccan. Tehran, Amir Kabir.

Alemi, K., \& Seyyedeh, L. M. S. (2017). Tipu Sultan's Role in Forming India's Independence Fields. Review of European Studies, 9(1), 226-233. https://doi.org/10.5539/res.v9n1p226 
Alnadwi, M. D. (1979). Moa'jam al-Amkenah. Encyclopedia of Uthmaniyah, Hyderabad, Deccan.

Barbosa, D. (1989). The book of Duarte Barbosa. Delhi.

Bungardelvin, A. G., \& Kotovski, G. G. (1982). The new history of India. Tehran, Beynolmelal.

Correia, A. (1981). Indo-Portuguese History. Oxford, U.P.

Cunningham, A. (1871). The Ancient Geography of India. London.

Dalboquerque, A. (1877). The Commentaries of the Great Afonso Dalboquerque. Walter De Gray Birch, London.

Dordi, E., \& Mirza, I. (n.d.). Translation of the Dehkan History. In Museum of the Salar Jang, Hyderabad (No. 418).

Fereshte, M. Q. H. S. (1883). Golshah Ebrahimi. Kanpour.

Gawan, K. E. M. (1948). Riyadh Al-Ensha, to the efforts of Gholam Yazdani. Hyderabad Deccan.

Gibb, H. A. R. (1929). Travels in Asia and Africa. London.

Hamedani, R. D. F. (2005). Jamea al-Tawarikh (History of India, Sind and Kashmir). Tehran.

Hemyari, M. B. A. M. (1975). Al-Rouz al-Mata'ar fi-khabar al Aghtar. Ehsan Abbas's research, Beirut.

Hourani, G. F. (1963). Arab Seafaring. Beirut.

Ibn Battuta, A. A., \& Mohammad, I. E. A. (1906). Rahlah. Dare sader, Beirut.

Ibn, J. (1967). Rahlah. Beirut.

Ibn, M. S., Bandare, G., \& Sheikh, S. A. (1993). Al-Fawaed Fi osul Alam Al-Bahrl-Alqawaed. In Cultural Works and Performers. Tehran.

Jalali, S. M. R. (1996). India in one look. Tehran: Shiraze Publishers.

Joshi, P. M. (1974). Historical Geoghraphy of Medieval Deccan. In Sherwani, \& Joshi (Eds.), History of Medieval Deccan. Andrapradesh.

Kabbur, N. G. (1984). Some aspects of land-use and settlement Geography of coastal karnataka (Ph. D. Thesis).

Karami, M. (1993). A Look at the History of Hyderabad. Deccan, Tehran, Ministry of Foreign Affairs Publishing.

Khafi, K., \& Mohammad, H. (1925). Montakhab Al-lobab. Calcutta.

Maghbul, A. (1954). Wasf al-Hind and Ma yojaweroha Menal-Belad. Al-Islamiyya Society, Aligar.

Neemdehi, A. A. (n.d.). Tabaghat Mahmood Shahi. Manuscript, London Windsor Library.

Nehru, J. L. (1982). Discover if India. Tehran: Amirkabir publishers.

Rapson. (1962). The sub-continent of India. In Cambridge History of India. Delhi.

Samarqandi, K. A. R. (2004). Matla'a saadein and Majm a'a Bahrein. Institute for Human Sciences and Cultural Studies, Tehran.

Sharif, E., \& Aby, A. (1989). Nozhah al-Moshtaq fi Ekhteragh al-Afaq. The Book of the World, Beirut.

Shirazi, R. D. (n.d.). Tazkera al-Muluk. Manuscript, Salar Jang Museum, Hyderabad.

Speight, E. E. (1935). The Coins of Bahmani kings of the Deccan. In Islamic Culture. Hyderabad.

Tibbetts, G. R. (1981). Arab Navigation in the Indian Ocean. London.

Tipu, S. (n.d.). Tipu sultan commands. In Mysore, Government Archives (No. 1).

Unknown author. (1993). India's rebellion. Tehran: Niloufar publishers.

Yazdani, G. (1960). The Early History of the Deccan. Oxford university.

Zaynaddin, I. A. A. (1987). Tohfat Al-Mujahideen Fi Ba'az Al Akhbar Al Porteghalyyein. Amin Toufiq Tayyebi's Excellency, Invitation to Al-Islam, Tripoli.

Zia al-Din, M. (n.d.). Dehkan's history or Riyadh-e-Rahman, famous for the history of Amjadiyah. 


\section{Copyrights}

Copyright for this article is retained by the author(s), with first publication rights granted to the journal.

This is an open-access article distributed under the terms and conditions of the Creative Commons Attribution license (http://creativecommons.org/licenses/by/4.0/). 